\title{
Smooth-muscle myosin mutations in hereditary non-polyposis colorectal cancer syndrome
}

\author{
N Vickaryous', G Polanco-Echeverry', S Morrow', N Suraweera', H Thomas ${ }^{2}$, I Tomlinson ${ }^{3}$ and A Silver ${ }^{*, I}$ \\ 'Colorectal Cancer Genetics, Institute for Cell and Molecular Sciences, Barts and The London School of Medicine and Dentistry, Queen Mary University of \\ London, Blizard Building, 4 Newark St, Whitechapel, London EI 2AT, UK; ${ }^{2}$ Family Cancer Clinic, St Mark's Hospital, Harrow HAI 3UJ, UK; ${ }^{3}$ Molecular \\ and Population Genetics Laboratory, London Research Institute, Cancer Research UK, London WC2A 3PX, UK
}

We examined adenomas and cancers from hereditary non-polyposis colorectal cancer (HNPCC) syndrome patients for the presence of frameshift mutations in the smooth-muscle myosin gene, MYHII. Our results show that mutations in MYHII occur more frequently in cancers than adenomas $(P=0.008)$ and are dependent on microsatellite instability $(\mathrm{MSI}+)$.

British Journal of Cancer (2008) 99, I726- |728. doi:I0.1038/sj.bjc.6604737 www.bjcancer.com

Published online 21 October 2008

(c) 2008 Cancer Research UK

Keywords: hereditary non-polyposis colorectal cancer; microsatellite instability; smooth-muscle myosin

DNA microsatellite instability (MSI + ) is a hallmark of tumours where there is loss of a mismatch repair (MMR) protein. This is exemplified in patients with hereditary non-polyposis colorectal cancer (HNPCC), an autosomal-dominant syndrome defined by predisposition to colorectal cancer (CRC; $2-5 \%$ of all incident cases) and to other cancers, including endometrial, stomach and ovarian cancer. Genetically, HNPCC is characterised by germline mutation and somatic inactivation of the MMR genes (Liu et al, 1996; Lynch and Smyrk 1996; Lagerstedt Robinson et al, 2007). MSI + CRCs also account for approximately $15 \%$ of all sporadic cases. Microsatellites have been characterised as being prone to frameshift mutations in MSI + cancers and mutations in coding regions of genes such as TGF $\beta R I I, B A X$, and MSH6, have been implicated in contributing to the neoplasia phenotype (Johannsdottir et al, 2000).

The genetic pathways of colorectal tumorigenesis in HNPCC and sporadic MSI + CRCs may overlap. Indeed, much of what we know about HNPCC has been conflated with that of the more common sporadic MSI + CRCs. However, there are a number of important differences, particularly with regard to $K-R A S, B R A F$, and $\beta$-catenin mutational frequencies (Johnson et al, 2005a, b; Loughrey et al, 2007). Recently, the SM2 isoform of the smoothmuscle myosin gene, (MYH11) was implicated in human intestinal neoplasia. Somatic frameshift mutations at a coding region containing a repeat of eight cytosines, $(C)_{8}$, in the final exon of MYH11 were identified in sporadic MSI + cancers and a germline frameshift mutation was also described in a Peutz-Jeghers syndrome patient (Alhopuro et al, 2008). To establish the contribution, timing and frequency of the MYH11 frameshift mutation in HNPCC tumorigenesis, we analysed a series of adenomas and cancers from HNPCC patients.

*Correspondence: Professor A Silver; E-mail: a.r.silver@qmul.ac.uk Received I 4 July 2008; accepted 24 September 2008; published online 21 October 2008

\section{MATERIALS AND METHODS}

\section{Patients}

Hereditary non-polyposis colorectal cancer was diagnosed based on previously reported criteria and national ethics guidelines were followed (Johnson et al, 2005a, b). A total of 77 HNPCC individuals from 60 families were selected and 34 adenomas plus 53 CRCs collected. Cancers were obtained from the distal and proximal colon and all grade from poor to well-differentiated and Duke stages A-C were represented as well as tumours that had metastasised to distant sites (D). Four endometrial cancers were also investigated. Hereditary non-polyposis colorectal cancer matched normal tissue was available for 41 samples.

\section{Mutation analysis}

DNA was prepared by dissection of neoplastic and normal areas from paraffin-embedded tissue followed by a proteinase $\mathrm{K}$ digestion. MSI status was defined using microsatellite markers $B A T-25, B A T-26, D 2 S 123, D 5 S 346$, and D17S250 analysed on an ABI-3100 genetic analyzer and classified as MSI + as per Bethesda guidelines (Boland et al, 1998).

The MYH11 mutation was examined using labelled primers flanking the $(\mathrm{C})_{8}$ tract (accession no. NM_022844; nucleotide nos. 5898-5905) and analysed on an ABI-3100 genetic analyser. Detected mutations were verified using direct sequencing. Frequency of frameshift mutations at intronic $(C)_{8}$ tracts were determined with primer pairs flanking regions in DHX30, DDELF1, ILIR 2 and PAK3 genes (Alhopuro et al, 2008). Primer details are available on request.

\section{Statistics}

Fisher's exact test was used to test for significance using Stata 8.2 (statistical software release 8.0; Stata corporation College Station, TX, USA). 
Table I Frequency of MYHI I frameshift mutations in HNPCC tumours

\begin{tabular}{lccccc}
\hline & $\mathbf{C 8} / \mathbf{C 8}^{\mathbf{a}}$ & $\mathbf{C 7 / C 8}$ & $\mathbf{C 8 / C 9}$ & $\mathbf{C 7 / C 8} \mathbf{C q}^{\mathbf{b}}$ & $\begin{array}{c}\text { Mutation } \\
\text { rate }\end{array}$ \\
\hline Normal & $4 I$ & 0 & 0 & 0 & $0 / 4 \mid(0 \%)$ \\
MSI- adenoma & 14 & 0 & 0 & 0 & $0 / 14(0 \%)$ \\
MSI- cancer & 6 & 0 & 0 & 0 & $0 / 6(0 \%)$ \\
MSI+ adenoma & 19 & 1 & 0 & 0 & $1 / 20(5 \%)$ \\
MSI+ cancer & 30 & 13 & 2 & 2 & $17 / 47(36 \%)$ \\
Endometrial cancer & 2 & 2 & 0 & 0 & $2 / 4(50 \%)$ \\
\hline
\end{tabular}

aild type alleles. ${ }^{\mathrm{b}}$ Indicates tumour heterogeneity.

\section{RESULTS AND DISCUSSION}

The $(\mathrm{C})_{8}$ repeat tract in the last exon of the SM2 isoform of MYH11 was examined in 87 HNPCC intestinal tumours. MSI + adenomas had a mutation rate of $5 \%(1 / 20)$ with a single adenoma carrying a frameshift mutation in one allele (Table 1). In contrast to MSI+ adenomas, MSI + cancers had a much higher rate of frameshift mutation $(36 \%, 17$ out of $47 ; P=0.008$; Table 1$)$. There were fewer mutations in our HNPCC MSI + cancers (36\%) compared with the sporadic MSI + cancers (55\%) reported by Alhopuro et al (2008) and this difference was significant $(P=0.04)$. We also investigated four MSI + endometrial cancers and found MYH11 frameshift mutations in $50 \%$ of samples ( 2 out of 4 ; Table 1 ). No frameshift mutations were found in the matched normal DNA $(n=41)$ from HNPCC patients, confirming the somatic origin of mutations. There were also no mutations found in microsatellite stable (MSI-) adenomas $(n=14)$ or MSI- cancers $(n=6$; Table 1$)$.

A concern when analysing allele mutation frequency in MSI + tumours is the confounding issue of passenger mutations that do not contribute to neoplasia. We assessed mutation frequency at four loci containing intronic $(C)_{8}$ repeat tracts in which any frameshift mutation would not be predicted to be selected for and would therefore represent passenger mutations (Alhopuro et al, 2008). We found that mutation frequencies at the intronic $(C)_{8}$ repeats were higher in HNPCC MSI + cancers (16\% of all loci, 29 out of 179) as compared with MSI + adenomas (7\% of all loci, 5 out of $69 ; P=0.07)$ indicating increased passenger mutation rates in the MSI + CRCs. More importantly, MSI + cancers had significantly higher frameshift mutation rates in MYH11 than at the intronic repeats (36 vs $16 \%, P=0.004$ ). MSI + adenomas however, displayed no difference between frequency of MYH11 $(5 \%, 1$ out of 20$)$ and intronic $(C)_{8}$ frameshift mutations $(7 \%, 5$ out of $69 ; P=1.0)$ These results indicate that frameshift mutations at MYH11 do not play a role in early stages of tumour formation, but are likely to play a role in progression of HNPCC tumorigenesis.

We next investigated whether there were associations between the presence of an MYH11 mutation and pathological features such
Table 2 Pathological features of HNPCC tumours and frequency of MYHI I mutation

\begin{tabular}{|c|c|c|c|c|c|}
\hline & $\begin{array}{c}\text { Number } \\
\text { of } \\
\text { samples }\end{array}$ & $\begin{array}{l}\text { Number } \\
\text { without } \\
\text { mutation }\end{array}$ & $\begin{array}{c}\text { Number } \\
\text { with } \\
\text { mutation }\end{array}$ & $\begin{array}{l}\text { Mutation } \\
\text { frequency }\end{array}$ & $P$-value \\
\hline \multicolumn{6}{|l|}{ Dukes stage $\mathrm{e}^{\mathrm{a}}$} \\
\hline$A+B$ & 21 & 15 & 6 & $29 \%$ & \\
\hline$C+D$ & 12 & 9 & 3 & $25 \%$ & 1.0 \\
\hline Total & 33 & 24 & 9 & & \\
\hline \multicolumn{6}{|l|}{ Tumour grade } \\
\hline Well differentiated & 3 & 3 & 0 & $0 \%$ & \\
\hline $\begin{array}{l}\text { Moderately } \\
\text { differentiated }\end{array}$ & 22 & 16 & 6 & $27 \%$ & \\
\hline $\begin{array}{l}\text { Poorly } \\
\text { differentiated }\end{array}$ & 4 & 2 & 2 & $50 \%$ & 0.4 \\
\hline Total & 29 & 21 & 8 & & \\
\hline \multicolumn{6}{|l|}{ Tumour site } \\
\hline Proximal location & 13 & 9 & 4 & $31 \%$ & \\
\hline Distal location & 12 & 9 & 3 & $25 \%$ & 1.0 \\
\hline Total & 25 & 15 & 7 & & \\
\hline
\end{tabular}

a Dukes stages $A-C$ and tumours that had metastasised to distant sites (D).

as Dukes stage, tumour grade and tumour site. Dukes stage was available for 33 cancers (Dukes $\mathrm{A}+\mathrm{B}, n=21$; Dukes $\mathrm{C}+\mathrm{D}, n=12$ ) and frameshift mutations were found in $29 \%$ (6 out of 21 ) of the $\mathrm{A}+\mathrm{Bs}$ and $25 \%$ (3 out of 12 ) of the $\mathrm{C}+\mathrm{Ds}$ indicating that mutation frequency was not increased in the more advanced Dukes stage ( $P=1.0$; Table 2$)$. A total of 29 cancers had tumour grade available and although the numbers in the well- and poorly differentiated grades were small, there was a trend towards an increase in mutation frequency with grade (well differentiated, $0 \%$, 0 out of 3 ; moderately, $27 \%, 6$ out of 22 ; poorly differentiated, $50 \%$, 2 out of 4 ; Table 2), but this was not significant $(P=0.4)$. Mutation frequency was not influenced by site of tumour presentation, distal or proximal $(P=1.0$; Table 2$)$.

In conclusion, our results indicate that the MYH11 mutation is not required for early HNPCC adenoma formation, but it is selected for in the process of MSI + cancer tumorigenesis. The role of MYH11 in the development of MSI + cancers merits further investigation particularly with respect to the underlying molecular and cellular mechanism.

\section{ACKNOWLEDGEMENTS}

We thank the patients and their doctors. This work was supported by Cancer Research UK.

\section{REFERENCES}

Alhopuro P, Phichith D, Tuupanen S, Sammalkorpi H, Nybondas M, Saharinen J, Robinson JR, Yang Z, Chen LQ, Orntoft T, Mecklin JP, Jarvinen H, Eng C, Moeslein G, Shibata D, Houlston RS, Lucassen A, Tomlinson I, Launonen V, Ristimaki A, Arango D, Karhu A, Sweeney HL, Aaltonen L (2008) Unregulated smooth-muscle myosin in human intestinal neoplasia. PNAS 105: 5513-5518, doi:10.1073/pnas. 0801213105

Boland CR, Thibodeau SN, Hamilton SR, Sidransky D, Eshleman JR, Burt RW, Meltzer SJ, Rodriguez-Bigas MA, Fodde R, Ranzani GN, Srivastava S (1998) A National Cancer Institute Workshop on Microsatellite Instability for cancer detection and familial predisposition: development of international criteria for the determination of microsatellite instability in colorectal cancer. Cancer Res 58: 5248-5257
Johannsdottir JT, Jonasson JG, Bergthorsson JT, Amundadottir LT, Magnusson J, Egilsson V, Ingvarsson S (2000) The effect of mismatch repair deficiency on tumourigenesis; microsatellite instability affecting genes containing short repeated sequences. Int J Oncol 16: 133-139

Johnson V, Lipton LR, Cummings C, Eftekhar Sadat ET, Izatt L, Hodgson SV, Talbot I, Thomas HJ, Silver A, Tomlinson IP (2005a) Analysis of somatic molecular changes, clinicopathological features, family history and germline mutations in colorectal families: evidence for efficient diagnosis of HNPCC and for distinct groups of non-HNPCC families. $J$ Med Genet 42: 756-762

Johnson V, Volikos E, Halford S, Eftekhar Sadat ET, Popat S, Talbot I, Truninger K, Martin J, Jass J, Houlston R, Atkin W, Tomlinson IP, Silver AR (2005b) Exon 3 beta-catenin mutations are specifically associated 
with colorectal carcinomas in the hereditary non-polyposis colorectal cancer syndrome. Gut 54: 264-267, doi:10.1136/gut.2004.048132

Lagerstedt Robinson K, Liu T, Vandrovcova J, Halvarsson B, Clendenning M, Frebourg T, Papadopoulos N, Kinzler KW, Vogelstein B, Peltomaki P, Kolodner RD, Nilbert M, Lindbolm A (2007) Lynch syndrome (hereditary nonpolyposis colorectal cancer) diagnostics. J Natl Cancer Inst 99: 291-299

Liu B, Parsons R, Papadopoulos N, Nicolaides NC, Lynch HT, Watson P, Jass JR, Dunlop M, Wyllie A, Peltomaki P, de la Chapelle A, Hamilton SR,
Vogelstein B, Kinzler KW (1996) Analysis of mismatch repair genes in hereditary non-polyposis colorectal cancer patients. Nat Med 2: 169-174 Loughrey MB, Waring PM, Tan A, Trivett M, Kovalenko S, Beshay V, Young MA, McArthur G, Boussioutas A, Dobrovic A (2007) Incorporation of somatic BRAF mutation testing into an algorithm for the investigation of hereditary non-polyposis colorectal cancer. Fam Cancer 6: 01 - 10, doi:10.1007/s10689-007-9124-1

Lynch HT, Smyrk T (1996) Hereditary nonpolyposis colorectal cancer (Lynch syndrome). An updated review. Cancer (Phila) 78: 1149-1167 